Between January 2017 and July 2018 103 patients were included in a prospective study of erythropoietin (EPO) monitoring. The group consisted of $33 \%$ patients with oropharynx, $29 \%$ with oral cavity, $13 \%$ with nasopharynx, $6 \%$ with larynx, $6 \%$ with hypopharynx, $8 \%$ with unknown primary cancer, $4 \%$ with nasal cavity, and $1 \%$ with salivary gland cancer. Clinic stage: T4 - 50, T3 - 21, T2 - 14, T1 $10, \mathrm{TO}-8$, and N3-19, N2 - 61, N1 $10, \mathrm{NO}-13$. All patients received from one to four cycles of induction chemotherapy. EPO was measured in blood serum by enzyme-labelled chemiluminescent immunometric assay, using an Immulite 2000XPi analyser before the administration and on day 11 of each chemotherapy cycle.

During induction chemotherapy the EPO level was elevated in all patients, which is expressed by means of medians: $10.7(p=0.000001)$ in the middle of cycle $1 ; 10.9(p=0.66)$ before cycle 2; $14.35(p=0.000177)$ in the middle of cycle 2; $14.95(p=0.39)$ before cycle $3,17.00(p=0.00078)$ in the middle of cycle 3 , and 20.9 after cycle $3(p=0.41)$

The correlation analysis conducted indicates that the administration of one chemotherapy dose results in higher EPO release (two-fold increase in EPO concentration) which intensifies reticulocytes (REC) production but without haemoglobin concentration in reticulocytes (HGB-REC) growth. In consequence, it leads to a decrease in RBC and HGB concentration (29-32 cases). The administration of two and three chemotherapy doses results in the subsequent higher release of $E P O$, which does not intensify REC production. In consequence, anaemia increases (35 cases).

Key words: erythropoietin, cisplatin, carboplatin, erythropoietin receptor.

Contemp Oncol (Pozn) 2019; 23 (3): 178-182 DOI: https://doi.org/10.5114/wo.2019.89247

\section{The endogenous erythropoietin in correlation with other erythrocytic parameters in patients with head and neck squamous cell carcinoma treated with platinum- based induction chemotherapy}

\author{
Dominika Leś ${ }^{1}$, Maria Saduś-Wojciechowska², Tomasz Rutkowski ${ }^{1}$, \\ Andrzej Wygoda ${ }^{1}, K^{\prime}$ rzysztof Składowski ${ }^{3}$
}

\begin{abstract}
${ }^{1}$ Department of Radiotherapy and Chemotherapy, Maria Skłodowska-Curie Memorial Cancer Centre and Institute of Oncology, Gliwice Branch, Gliwice, Poland 2Department of Bone Marrow Transplantation and Haematology-Oncology, Maria Skłodowska-Curie Memorial Cancer Centre and Institute of Oncology, Gliwice Branch, Gliwice, Poland

3I Department of Radiotherapy and Chemotherapy, Maria Skłodowska-Curie Memorial Cancer Centre and Institute of Oncology, Gliwice Branch, Gliwice, Poland
\end{abstract}

\section{Introduction}

Cisplatin is one of the cytostatic agents that most frequently (47-100\%) causes anaemia through erythropoietin (EPO) production damage. This is, in most cases, mild anaemia. Anaemia is a negative prognostic factor for patients with cancer because it causes tumour hypoxia, which leads to chemotherapy and radiotherapy resistance, genetic instability, resistant clone selection, apoptosis impairment, and angiogenesis stimulation. This facilitates disease progression and formation of distant metastases, and in consequence leads to a negative prognosis.

EPO is a glycoprotein peptide hormone stimulating various erythropoiesis stages in bone marrow. It is produced in kidneys (80\%) and in liver (approximately 20\%). Hypoxia stimulates kidney interstitial cells to produce EPO.

At a sufficient iron reserve, the stimulation of erythroblastic system by EPO appears as an increase in the total count of reticulocytes (REC), an increase in the percentage of their immature fraction (IFR) = MFR (medium-mature reticulocytes fraction of medium fluorescence) + HFR (immature reticulocytes fraction of high fluorescence), and an increase in haemoglobin concentration in reticulocytes (HGB-REC).

Over the last decade, preclinical data has revealed that EPO is not only the hormone that regulates erythropoiesis but is also a cytokine with a pleiotropic activity affecting cancer cells.

EPO and its receptor expression (EPO-R) has been found in many cancers of various origins. The EPO/EPO-R arrangement is active in many cancer cells and it takes part in the modification of molecular signal tracks and the stimulation of growth, survival, mobility, and ability to form metastases. EPO may increase the resistance of cancer cells to chemotherapy and radiotherapy. The impact of EPO on the tumour cells depends on a carcinoma type, expression level and EPO-R function in the cells of a specific carcinoma, micro-environment (hypoxia), and the type of administered anti-carcinoma treatment (both synergistic and antagonistic activity).

The aim of the study was to evaluate the concentrations of EPO in correlation with other erythrocytic parameters in the blood of patients with ad- 
vanced head and neck squamous cell carcinoma (HNSCC) treated with platinum-based induction chemotherapy.

\section{Material and methods}

Between January 2017 and December 2018, 103 patients with HNSCC, treated with platinum-based induction chemotherapy, were qualified for prospective EPO monitoring (Tables 1 and 2).

The most common adverse effects of cisplatin were as follows: anaemia, nephrotoxicity, ototoxicity, and polyneuropathy. Therefore, the inclusion criteria for patients into the treatment comprised: good overall condition (ZUBROD $<2)$, $\mathrm{Hb}$ concentrations $>9 \mathrm{~g} / \mathrm{dl}$, glomerular filtration rate $(G F R)>60 \mathrm{ml} / \mathrm{min}$ and normal creatinine values, lack of hearing loss over one degree according to Common Terminology Criteria for Adverse Events (CTCAE), and lack of polyneuropathy above grade one according to CTCAE. Wilcoxon signed-rank test was used in statistical calculations.

All patients received from one to four cycles of induction chemotherapy based on the following patterns: TPF (docetaxel $75 \mathrm{mg} / \mathrm{m}^{2}$ on day 1 , cisplatin $75 \mathrm{mg} / \mathrm{m}^{2}$ on day 1, 5-fluorouracil $750 \mathrm{mg} / \mathrm{m}^{2}$ on day1-5), PF (cisplatin $100 \mathrm{mg} / \mathrm{m}^{2}$ on day 1,5 -fluorouracil $1000 \mathrm{mg} / \mathrm{m}^{2}$ on day $1-4)$, carboplatin according to AUC 5 on day $1+5$ fluorouracil (5 Fu) $1000 \mathrm{mg} / \mathrm{m}^{2}$ on day 1-4, carboplatin according to AUC 5 + paclitaxel (PXL) $175 \mathrm{mg} / \mathrm{m}^{2}$, PAC (cisplatin $50 \mathrm{mg} / \mathrm{m}^{2}$, cyclophosphamide $500 \mathrm{mg} / \mathrm{m}^{2}$, doxorubicin $50 \mathrm{mg} / \mathrm{m}^{2}$ ), or cisplatin $100 \mathrm{mg} / \mathrm{m}^{2}$ (Table 3). In about 20\% (22) of patients there was a delay in the administration of cycle 2 or 3 , generally due to neutropaenia of at least grade 2 according to CTCAE.

EPO concentration in plasma and erythrocytic parameters: REC, HGB-REC, erythrocytes (RBC), Hb, MFR, HFR, IFR (IFR $=$ MFR + HFR), and LFR (mature reticulocytes fraction of low fluorescence) were measured in the following points: before cycle 1 of chemotherapy, on day 11 of cycle 1 , before cycle 2, on day 11 of cycle 2 , before cycle 3 , on day 11 of cycle 3, and after three cycles of chemotherapy.

Endogenic EPO was measured in blood serum by enzyme-labelled chemiluminescent immunometric assay, using an Immulite 2000XPi analyser before the administration and on day 11 of each chemotherapy cycle.

\section{Results}

The analysis involved 103 patients who received from one to four cycles of induction chemotherapy.

Initial (i.e. before chemotherapy/initiation of treatment) EPO levels were at the lower limit or even below the normal range $(4.3-29.0 \mathrm{mlU} / \mathrm{ml})$, median: 8.4 and mean: 10.15. During induction chemotherapy, EPO levels increased in all the patients (Table 4).

Iron (Fe) metabolism parameters were determined in all the patients. In most cases there was chronic disease anaemia. Patients did not require supplementation of Fe preparations. Supplementation was conducted only in the case of Fe deficiency anaemia, in approximately $5 \%$ of cases (generally due to the tumour haemorrhage).

Differences between EPO1 and EPO2, EPO3 and EPO4, and EPO5 and EPO6 were statistically significant.

The EPO increase was found in a considerable number of patients in the middle of each chemotherapy cycle and then returning towards the initial values before the administration of subsequent treatment cycles.

In the analysed group, there was an increase in creatinine value (up to $107 \mathrm{mmol} / \mathrm{l}$ in one patient); creatinine concentrations were correct in the remaining patients. Eighty-nine patients (80\%), after finishing induction chemotherapy, were treated radically. In the case of the remaining 14 patients (20\%), due to the lack of any response to induction chemotherapy, palliative treatment was administered. There was rapid disease recurrence or dissemination among 28 patients treated radically (27\%).

\section{Initial erythrocytic parameters}

Before chemotherapy, with a lack of anaemia, higher EPO concentrations stimulate REC production, but this is not reflected in the $\mathrm{HGB}$ and $\mathrm{RBC}$ concentration increase, and consequently it leads to anaemia accompanying cancer (92 cases). During platinum-based chemotherapy, EPO concentration growth can be observed (Table 5).

1. The administration of one chemotherapy dose results in higher EPO release (two-fold increase in EPO concentration), which intensifies REC production but without HGB-REC growth. In consequence, it leads to the decrease in RBC and HGB concentration (29-32 cases).

Table 1. Characteristics of 103 patients who received platinum-based chemotherapy

$\begin{array}{lcccccc}\text { Diagnosis } & \begin{array}{c}\text { Oropharynx } \\ \text { cancer }\end{array} & \begin{array}{c}\text { Nasopharynx } \\ \text { cancer }\end{array} & \begin{array}{c}\text { Oral } \\ \text { cavity } \\ \text { cancer }\end{array} & \begin{array}{c}\text { Larynx } \\ \text { cancer }\end{array} & \begin{array}{c}\text { Unknown } \\ \text { primary } \\ \text { cancer }\end{array} & \begin{array}{c}\text { Hypopharynx } \\ \text { cancer }\end{array} \\ \begin{array}{l}\text { Number } \\ \text { of patients }\end{array} & 33 & 14 & 30 & 7 & 8 & \begin{array}{c}\text { Nasal } \\ \text { cavity } \\ \text { cancer } \\ \text { gland } \\ \text { cancer }\end{array}\end{array}$

Table 2. Clinic stage

$\begin{array}{lccccc}\text { Tumour size }(\mathrm{T}) & \text { T4 } & \text { T3 } & \text { T2 } & \text { T1 } & \text { T0 } \\ \text { Number of patients } & 50 & 21 & 14 & \text { N1 } & \text { N0 } \\ \text { Lymphatic glands }(\mathrm{N}) & \text { N3 } & \text { N2 } & 61 & 10 & 13\end{array}$


2. The administration of two and three chemotherapy doses results in the subsequent increase of EPO release, which does not intensify REC production. In consequence, anaemia increases (35 cases).

\section{Conclusions}

1. Platinum-based chemotherapy results in the increase of EPO concentration.

2. The EPO concentration increase, despite the symptoms of erythroblastic system stimulation, does not lead to the prevention of carcinoma-related anaemia, which progresses probably due to platinum toxicity.

\section{Discussion}

The endogenous EPO concentration during induction chemotherapy based on platinum derivatives in patients with advanced HNSCC is variable. At the time of chemotherapy lasting from one to three cycles, the EPO concentration increases; probably it takes place within a few days after the administration of cytotoxic agents.

Fe is retained in macrophages as a result of the stimulation of the immunological system by pro-inflammatory factors and carcinoma cells, leading to the activation of monocytes and lymphocytes and the production of TNF- $\alpha$ and interleukins in chronic diseases anaemia accompanying cancer. Their presence affects the production of acutephase protein and hepcidin. Fe is retained in the reticuloendothelial system, which leads to the limitation of its availability for progenitor cells, which in turn causes erythropoiesis in the conditions of Fe deficiency.

Pro-inflammatory and anti-inflammatory cytokines variously affect the Fe uptake by macrophages. TNF- $\alpha$ induces erythrophagocytosis through the stimulation of proper receptors on macrophages, which destroy erythrocytes, shortening their survival time. In consequence, the Fe level lowers and Fe deficiency leads to the limitation of erythropoiesis and anaemia development. The route of releasing Fe from macrophages is also blocked - IFN- $\gamma$ disrupts the ferroportin expression on monocytes, which

Table 3. Number of treatment cycles

$\begin{array}{lcccc}\begin{array}{l}\text { Number of } \\ \text { chemotherapy cycles }\end{array} & \text { cycle } \mathbf{1} & \text { cycles 2 } & \text { cycles } 3 & \begin{array}{c}\text { Over } \\ \text { 3 cycles }\end{array} \\ \text { Number of patients } & 7 & 25 & 65 & 6\end{array}$

causes excessive Fe retention in such cells. The concentration of available Fe is not sufficient for erythropoiesis. In addition, $\alpha$-1-antitrypsin, forming a bond with free receptors for transferrin (TfR), blocks Fe availability for progenitor cells, disabling their growth and diversification. It leads to the impairment of proliferation and diversification of erythroid cells.

The conducted correlation analysis of EPO and erythrocytic parameters clearly demonstrated a strong correlation between the concentrations of EPO, IFR, and REC. Nevertheless, the EPO growth is not reflected in an HGB-REC increase in all patients.

The measurement of haemoglobin content in reticulocytes provides the possibility of evaluating Fe availability for the needs of erythropoiesis and evaluating the quality of newly-produced erythrocytes. It enables the detection of changes in the haemoglobin level significantly earlier than the measurement of haemoglobin content in mature erythrocytes.

The main advantage of the RET-HGB parameter, with reference to ferritin and transferrin, is that it is not dependent on the acute phase state. RET-HGB is used in monitoring EPO therapy and/or Fe intravenous therapy. When the value increases, it indicates a positive response.

Receptors for EPO occur on early progenitor cells of erythropoiesis - burst forming unit-erythroid (BFU-E) cells. Their density grows in colony forming unit-erythroid (CFU-E) cells and drops along the subsequent maturity of erythroblasts. However, they are not present in the cell membrane of reticulocytes and erythrocytes.

The sign of EPO activity is an increase in the division and proliferation of CFU-E cells and consequently HFR and MFR, which, in a physiological situation, causes the growth in the erythrocytes count. In our patients there was no increase in the erythrocytes count because we used ineffective erythropoiesis. The gradual drop in RBC and HGB level observed in patients was caused by myelotoxicity of platinum-derivatives (mainly cisplatin), but other cytostatic agents also fulfilled their role here. This may explain the nephrotoxicity of platinum compounds because cisplatin damages the kidney interstitial cells where EPO is produced. Usually, as in our study, this is mild anaemia.

In the available literature [1-19], among patients with lowered HGB level and correct creatinine level, a gradual increase in EPO value could be observed as well (only

Table 4. The levels of endogenous erythropoietin (EPO) during platinum-derivative-based induction chemotherapy in patients with advanced head and neck squamous cell carcinoma

\begin{tabular}{|c|c|c|c|c|c|c|c|}
\hline EPO & $\begin{array}{c}\text { EPO1 } \\
(n=92) \\
\text { before cycle } 1\end{array}$ & $\begin{array}{c}\text { EPO2 } \\
(n=81) \\
\text { on day } 11 \\
\text { of cycle } 1\end{array}$ & $\begin{array}{c}\text { EPO3 } \\
(n=73) \\
\text { before cycle } 2\end{array}$ & $\begin{array}{c}\text { EPO4 } \\
(n=67) \\
\text { on day } 11 \\
\text { of cycle } 2\end{array}$ & $\begin{array}{c}\text { EPO5 } \\
(n=55) \\
\text { before cycle } 3\end{array}$ & $\begin{array}{c}\text { EPO6 } \\
(n=41) \\
\text { on day } 11 \\
\text { of cycle } 3\end{array}$ & $\begin{array}{c}\text { EPO7 } \\
(n=20) \\
\text { after } 3 \text { cycles }\end{array}$ \\
\hline Median & $\begin{array}{c}8.40 \\
(\min 1.3 \\
\max 101 \\
\mathrm{mlU} / \mathrm{ml})\end{array}$ & $\begin{array}{c}10.70 \\
(\min 2.9 \\
\max 40.5 \\
\mathrm{mIU} / \mathrm{ml})\end{array}$ & $\begin{array}{c}10.90 \\
(\min 3.3 \\
\max 104 \\
\mathrm{mlU} / \mathrm{ml})\end{array}$ & $\begin{array}{c}14.35 \\
(\min 1.5 \\
\max 81.6 \\
\mathrm{mlU} / \mathrm{ml})\end{array}$ & $\begin{array}{c}14.95 \\
(\min 4.6 \\
\max 156 \\
\mathrm{mlU} / \mathrm{ml})\end{array}$ & $\begin{array}{c}17.00 \\
(\min 8.1 \\
\max 134 \\
\mathrm{mlU} / \mathrm{ml})\end{array}$ & $\begin{array}{c}20.90 \\
(5.1 \\
\max 96.6 \\
\mathrm{mlU} / \mathrm{ml})\end{array}$ \\
\hline Mean $\pm S D$ & $10.15 \pm 10.64$ & $13.34 \pm 7.74$ & $13.68 \pm 12.18$ & $18.96 \pm 13.72$ & $20.35 \pm 20.87$ & $23.57 \pm 20.34$ & $26.65 \pm 22.48$ \\
\hline$p$ & & 0.0000001 & 0.66 & 0.000177 & 0.39 & 0.000780 & 0.41 \\
\hline
\end{tabular}


Table 5. Correlation analysis - the impact of three months' chemotherapy based on platinum derivatives on the erythropoietin (EPO) concentration and erythrocytic parameters in patients with head and neck carcinoma

\begin{tabular}{|c|c|c|c|c|c|c|c|}
\hline Parameter & $\begin{array}{c}\text { EPO1 } \\
(n=92) \\
\text { before cycle } 1 \\
n=92\end{array}$ & $\begin{array}{c}\text { EPO2 } \\
(n=81) \\
\text { on day } 11 \\
\text { of cycle } 1 \\
n=29\end{array}$ & $\begin{array}{c}\text { EPO3 } \\
(n=73) \\
\text { before cycle 2; } \\
\text { no } \\
\text { correlation }\end{array}$ & $\begin{array}{c}\text { EPO4 } \\
(n=67) \\
\text { on day } 11 \\
\text { of cycle } 2 \\
n=32\end{array}$ & $\begin{array}{c}\text { EPO5 } \\
(n=55) \\
\text { before cycle 3; } \\
\text { no } \\
\text { correlation }\end{array}$ & $\begin{array}{c}\text { EPO6 } \\
(n=41) \\
\text { on day } 11 \\
\text { of cycle } 3 \\
n=35\end{array}$ & $\begin{array}{c}\text { EPO7 } \\
(n=20) \\
\text { after } \\
3 \text { cycles } \\
n=14\end{array}$ \\
\hline EPO & $8.96 \pm 5.44$ & $11.83 \pm 7.16$ & & $18.82 \pm 16.45$ & & $23.55 \pm 22.43$ & $20.60 \pm 17.55$ \\
\hline RBC & $\begin{array}{c}4.64 \pm 0.48 \\
-0.39^{\star}\end{array}$ & $\begin{array}{c}4.47 \pm 0.51 \\
-0.43^{*}\end{array}$ & & $\begin{array}{c}4.19 \pm 0.43 \\
-0.40^{\star}\end{array}$ & & $\begin{array}{c}3.96 \pm 0.40 \\
-0.46^{\star}\end{array}$ & $\begin{array}{c}4.01 \pm 0.44 \\
-0.71^{*}\end{array}$ \\
\hline REC\# & $64.91 \pm 20.98$ & $\begin{array}{c}75.64 \pm 31.69 \\
0.42^{\star}\end{array}$ & & $81.61 \pm 36.64$ & & $81.73 \pm 47.35$ & $87.36 \pm 32.93$ \\
\hline $\mathrm{Hb}$ & $\begin{array}{c}13.98 \pm 1.28 \\
-0.44^{*}\end{array}$ & $\begin{array}{c}13.36 \pm 1.57 \\
-0.50^{*}\end{array}$ & & $12.79 \pm 1.14$ & & $\begin{array}{c}12.13 \pm 1.18 \\
-0.36^{\star}\end{array}$ & $12.26 \pm 1.07$ \\
\hline IRF & $\begin{array}{c}9.73 \pm 4.70 \\
0.26^{*}\end{array}$ & $\begin{array}{c}13.57 \pm 6.62 \\
0.48^{\star}\end{array}$ & & $\begin{array}{c}17.70 \pm 10.25 \\
0.48^{*}\end{array}$ & & $17.97 \pm 8.22$ & $17.30 \pm 7.55$ \\
\hline HGB-REC & $32.81 \pm 2.26$ & $33.63 \pm 2.21$ & & $33.70 \pm 2.13$ & & $34.79 \pm 2.85$ & $33.41 \pm 4.59$ \\
\hline
\end{tabular}

Correlation coefficients labelled with an asterisk are significant at $p<0.05$

among patients under chemotherapy based on platinum) from the first to the last chemotherapy cycle and an increase in EPO concentration after nearly every chemotherapy cycle based on platinum (in particular, an increase in the middle of each cycle, which is probably caused by higher sensitivity of a mechanism responsible for EPO release after platinum injection, and then a drop towards the initial level before administering another cycle). Kidney efficiency was not related to EPO production.

The study presented includes various interpretations of EPO increase after cytostatic agent treatment:

1) cytostatic therapy, while damaging directly the cells producing EPO in kidneys, imitates their hypoxia,

2) inhibiting the activity of a bone marrow stimulates unknown factors for EPO production,

3) decreasing erythrocytes precursors disturbs the regular route of EPO degradation.

The observed RBC and HGB level decrease was caused by:

1) direct myelotoxicity of platinum compounds and other administered cytostatic agents,

2) nephrotoxicity of platinum compounds that damage interstitial kidney cells where EPO is produced.

High fluctuations in EPO-R level through EPOR induction on HNSCC cells may stimulate the proliferation of tumour cells resistant to induction chemotherapy. This may cause disease progression/recurrence even if, after induction chemotherapy, disease regression was obtained.

\section{Conclusions}

Summarising - cyclic fluctuations of EPO concentration during induction chemotherapy and the successive increase in EPO level during treatment was observed.

The group of patients with post-treatment progression of disease should be analysed separately. So far, a group of 42 patients was analysed with post-treatment disease progression. High fluctuations of EPO level and an overall EPO increase were observed in this group. In those with peaks and general high increase in EPO concentration, rapid recurrences, distant metastasis or treatment failure can be expected. Such fluctuations may induce EPO-R in HNSCC cells and stimulate proliferation of clonogenic cells resistant to induction chemotherapy even if there is significant or complete regression after induction treatment.

On the basis of the available literature, we know that EPO may stimulate the growth, ability for metastasis, and drug resistance in cell lines of head and neck carcinoma. These preliminary results should be confirmed in further studies.

The authors declare no conflict of interest.

\section{References}

1. Radziwon P, Krzakowski M, Kalinka-Warzocha E, Zaucha R, Wysocki P, Kowalski D, Gryglewicz J, Wojtukiewicz MZ. Niedokrwistość u chorych na nowotwory. Oncol Clin Pract 2017; 13: 202-210.

2. Acs G, Acs P, Beckwith SM, Pitts RL, Clements E, Wong K, Verma A. Erythropoietin and erythropoietin receptor expression in human cancer. Cancer Res. 2001; 61: 3561-3565.

3. Riley RS, Ben-Ezra JM, Goel R, Tidwell A. Reticulocytes and reticulocyte enumeration. J Clin Lab Anal 2001; 15: 267-294.

4. Szenajch J, Synowiec A. Erythropoietin and drug resistance in breast and ovary cancer. Ginekol Pol 2016; 87: 300-304.

5. Elliott S, Busse L, Bass MB, et al. Anti-Epo antibodies do not predict Epo receptor expression. Blood 2006; 107: 1892-1985.

6. Brown WM, Maxwell P, Graham AN, Yakkundi A, Dunlop EA, Shi Z, Johnston PG, Lappin TR. Erythropoietin receptor expression in nonsmall cell lung carcinoma: a question of antibody specificity. Stem Cells 2007; 25: 718-722.

7. Della Ragione F, Cucciolla V, Borriello A, Oliva A, Perrotta S. Erythropoietin receptors on cancer cells: a still open question. J Clin Oncol 2007; 25: 1812-1813.

8. Chretien S, Moreau-Gachelin F, Apiou F, et al. Putative oncogenic role of the erythropoietin receptor in murine and human erythroleukemia cells. Blood 1994; 83: 1813-1821.

9. Migliaccio AR, Bruno M, Migliaccio G. Evidence for direct action of human biosynthetic (recombinant) GM-CSF on erythroid progenitors in serum-free culture. Blood 1987; 70: 1867-1871.

10. Arcasoy MO, Edgar BA, Harris KW, Forget BG. Familial erythrocytosis associated with a short deletion in the erythropoietin receptor gene. Blood 1997; 89: 4628-4635. 
11. Vaupel P, Mayer A, Höckel M. Impact of hemoglobin levels on tumor oxygenation: The higher, the better? Strahlenther Onkol 2006; 182: 63-71.

12. Arcasoy MO. Erythropoiesis-stimulating agent use in cancer: preclinical and clinical perspectives. Clin Cancer Res 2008; 14: 46854690.

13. Hadland BK, Longmore GD. Erythroid-stimulating agents in cancer therapy: potential dangers and biologic mechanisms. J Clin Oncol 2009; 27: 4217-4226.

14. Fender J. Erythropoietin receptors on tumor cells: what do they mean? Oncologist 2008; 13: 16-20.

15. Swift S, Ellison AR, Kassner P, McCaffery I, Rossi J, Sinclair AM, Begley CG, Elliott S. Absence of functional EpoR expression in human tumor cell lines. Blood 2010; 115: 4254-4263.

16. Sinclair AM, Coxon A, McCaffery I, et al. Functional erythropoietin receptor is undetectable in endothelial, cardiac, neuronal, and renal cells. Blood 2010; 115: 4264-4272.

17. Kirkeby A, Van BJ, Nielsen J, Leist M, Helboe L. Functional and immunochemical characterisation of different antibodies against the erythropoietin receptor. J Neurosci Methods 2007; 164: 50-58.

18. Laugsch M, Metzen E, Svensson T, Depping R, Jelkmann W. Lack of functional erythropoietin receptors of cancer cell lines. Int I Cancer 2008; 122: 1005-1011.

19. Canapro R, Casale F, Muntoni E, et al. Plasma erythropoetin concentrations in patients receiving intensive platinum or non-platinum chemotherapy. Br J Pharmacol 2000; 50: 146-153.

\section{Address for correspondence}

\section{Dominika Leś}

Department of Radiotherapy and Chemotherapy

Maria Skłodowska-Curie Memorial Cancer Centre

and Institute of Oncology, Gliwice Branch

15 Wybrzeże Armii Krajowej St.

44-100 Gliwice, Poland

e-mail: dominika.les@io.gliwice.pl

Submitted: 22.03.2019

Accepted: 21.06.2019 